\title{
Hubungan antara Kadar Timbal Udara dengan Kadar Timbal Darah Serta Dampaknya pada Anak
}

Anna F. Wagiu, F. H. Wulur

Latar belakang. Pencemaran timbal $(\mathrm{Pb})$ di udara masih menjadi masalah pediatri sosial. Keracunan kronis pada anak akan berdampak pada gangguan fisik dan mental. Tujuan. Untuk mengetahui tingkat pencemaran timbal di udara serta dampak kesehatan yang ditimbulkan pada anak di Kota manado.

Bahan dan cara. Analitik observasional potong lintang dilakukan antara bulan Mei sampai Juli 2005. Sampel, anak yang berusia 6-13 tahun bermukim di Pusat Kota Pasar 45 dan di Tingkulu sebagai kontrol. Kadar timbal udara diukur menggunakan high volume sampler dianalisis dengan metode atomic absorption spectrophotometer (AAS), kadar timbal darah dengan metode AAS dan kadar hemoglobin dengan metode Sianmethemoglobin.

Hasil. Subyek terdiri 75 orang anak yaitu 40 subyek kelompok Pasar 45 dan 35 subyek kontrol. Terbanyak pada kelompok Pasar 45 perempuan 28(58,3\%) dan kontrol 20 $(41,7 \%)$ perempuan. Kadar timbal di udara lokasi Pasar 45 adalah 0,799 ig/ $\mathrm{m}^{3}$ dan kontrol 0,237 ìg/ $\mathrm{m}^{3}$. Pada lokasi Pasar $45 \mathrm{kadar}$ timbal darah antara $10-19 \mathrm{ig} / \mathrm{dL}$ terdapat pada satu anak $(2,5 \%)$ dan $>0-10 \mathrm{ig} / \mathrm{dL}$ pada 39 anak $(97,5 \%)$ sedangkan kontrol $(100 \%)<0,2 \mathrm{ig} / \mathrm{dL}$. Tidak terdapat hubungan kadar timbal udara dengan kadar timbal darah anak di Pasar 45 dan kontrol $(\mathrm{p}=0,346)$. Terdapat hubungan yang bermakna antara kadar $\mathrm{Hb}$ dengan kadar timbal darah anak di Pasar 45 ( $\mathrm{p}=0,016)$. Tidak didapatkan hubungan bermakna antara hitung retikulosit dengan kadar timbal darah anak di Pasar $45(\mathrm{p}=0,812)$.

Kesimpulan. Kadar timbal udara di Pasar 45 tidak melebihi ambang baku mutu. Tidak terdapat hubungan kadar timbal udara dengan kadar timbal darah di Pasar 45. Terdapat hubungan bermakna antara kadar $\mathrm{Hb}$ dengan kadar timbal darah anak di Pasar 45. Walaupun masih dalam derajat ringan telah terjadi peningkatan kadar timbal darah pada anak yang tinggal di pasar 45.

Kata kunci: kadar timbal udara, kadar timbal darah, kadar $\mathrm{Hb}$, hitung retikulosit.

Alamat korespondensi:

Dr. Anna F. Wagiu, Sp.A

Dr. F. H. Wulur Sp.A(K).

Bagian/SMF Ilmu Kesehatan Anak FK UNSRAT/RSU Prof. Dr. R. D.

Kandou Jl. Raya Tanahwangko,Manado 95263

Telepon. 62-431-821652, Fax.62-431-859091.

E-mail:ikarsup@telkom.net

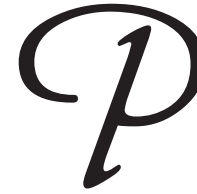

olusi udara akibat asap kendaraan bermotor di kota-kota besar seperti Jakarta, Medan, Bandung, Surabaya dan kota lain semakin parah. ${ }^{1}$ Menurut data Menteri KLH (dikutip dari Pirngadie ${ }^{2}$ ), kendaraan bermotor dapat menghasilkan gas buangan yang berbahaya sebanyak CO 70\%, Pb 100\%, HC 100\% 
dan NOx $60 \%$. Industri otomotif dunia telah mengembangkan teknologi kendaraan bermotor ramah lingkungan sejak 1991-2004 dengan memperkenalkan Standar Euro I-IV. Indonesia yang merupakan negara dengan jumlah penduduk terbesar ke lima belum menerapkan standar Euro ini. ${ }^{1,3}$ Jenis bahan bakar yang banyak digunakan di Indonesia adalah premium yang mempunyai nilai oktan 88 dengan kandungan timbal (tetraethyl lead) $3 \mathrm{~g} / \mathrm{L}$. Menurut world wide fuel charter (WWFC) standar nilai oktan minimum 91 sedangkan environment Protection Agency (EPA) menyatakan batas maksimum timbal dalam 1 liter bensin adalah 0,05 g. ${ }^{2}$

Kandungan timbal diperkirakan 90\% keluar bersama gas buangan knalpot dapat terhirup dan diserap tubuh. Anak adalah kelompok yang rentan., ${ }^{4,5}$ Timbal merupakan logam berat toksik tanpa fungsi sehingga tidak diperlukan oleh tubuh dan jika ada merupakan kontaminasi dari lingkungan. Timbal juga sangat lambat diekskresi oleh tubuh sehingga mudah terakumulasi dan menyebabkan gangguan fungsi organ serta aktivitas biokimia. Selain sistim susunan syaraf pusat (SSP), sistim hematopoetik juga sangat sensitif.6${ }^{8}$ Meskipun keracunan timbal akut jauh berkurang dibandingkan waktu lampau namun efek kronis akibat pemaparan timbal kadar rendah pada anak yang sedang mengalami tumbuh kembang akan berdampak pada pertumbuhan fisik dan mental. ${ }^{6-9}$

Di Indonesia penelitian pada anak masih terbatas. Penelitian oleh Pusat Penelitian Kesehatan (PPK) UI dari 400 anak SD kelas II dan III di Jakarta ditemukan $35,4 \%$ anak mempunyai kadar timbal $>10 \mu \mathrm{g} / \mathrm{dL} .^{3}$ Di Surabaya diteliti mengenai kadar timbal di udara ambien dan hubungan antara kadar timbal darah dengan IQ anak sekolah, Soesanto (dikutip dari Mukono ${ }^{9}$ ) menemukan kadar $\mathrm{Pb}$ di udara ambien pada daerah penelitian sebesar $0,00103 \mathrm{mg} / \mathrm{m}^{3}$, masih di bawah baku mutu yang besarnya $0,0060 \mathrm{mg} / \mathrm{m}^{3}$. Didapatkan juga kadar $\mathrm{Pb}$ darah anak SD di kawasan tertib lalu-lintas $39,73 \mu \mathrm{g} / 100 \mathrm{ml}$ lebih tinggi dari kadar $\mathrm{Pb}$ di luar kawasan tersebut $(16,73 \mu \mathrm{g} / 100 \mathrm{ml})$. Tidak ditemukan perbedaan yang bermakna antara IQ anak sekolah SD di kawasan dan di luar kawasan tertib lalu-lintas. Fathoni dkk, ${ }^{10}$ di Bandung meneliti kadar timbal darah pada 47 anak pekerja pabrik tekstil usia 6-24 bulan mendapatkan 45 anak (95,74\%) mempunyai kadar timbal antara $>0-10 \mu \mathrm{g} / \mathrm{dL}$ dan 2 anak (4,2 \%) kadar timbal darah 10-19 $\mu \mathrm{g} / \mathrm{dL}$. Penelitian Warouw, ${ }^{11}$ menemukan kadar $\mathrm{Pb}$ di udara Pusat Kota
Pasar 45 Manado telah mencapai rata-rata $1,789 \mu \mathrm{g} /$ $\mathrm{m} 3$ atau telah melewati baku mutu yang diberlakukan EPA dan WHO.

Tujuan penelitian ini adalah untuk mengetahui tingkat pencemaran timbal di udara serta dampak kesehatan yang ditimbulkan pada anak di Kota manado.

\section{Bahan dan Cara}

Penelitian analitik observasional potong lintang dilakukan pada bulan Mei sampai Juli 2005. Sampel adalah anak usia 6-13 tahun yang tinggal di Pusat Kota pasar 45 dan di Tingkulu sebagai kontrol. Kriteria inklusi adalah anak laki-laki/perempuan berusia 6-13 tahun, tinggal dan menetap di tempat tersebut sejak lahir dan orang tua/wali menandatangani informed consent. Kriteria eksklusi apabila anak yang sedang mengalami fraktur dan anak yang tinggal digedung tertutup /atau menggunakan alat pendingin. Besar sampel dihitung berdasarkan permasalahan korelatif, menggunakan $\alpha=$ 0,05 dan $\beta=0,20$ dan besarnya nilai koefisien $r=0,30$. Diperoleh besar sampel minimal 68 anak. Sampel diambil secara consecutive. Sedangkan variabel bebas pertama adalah kadar timbal di udara, variabel tergantung pertama adalah kadar timbal darah. Variabel bebas kedua adalah kadar timbal darah, variabel tergantung kedua adalah kadar Hemoglobin $(\mathrm{Hb})$ dan hitung retikulosit. Anak yang memenuhi kriteria inklusi dilakukan pengambilan darah $5 \mathrm{ml}$ untuk pemeriksaaan kadar timbal darah, kadar $\mathrm{Hb}$ dan hitung retikulosit. Kadar timbal di udara diukur menggunakan alat high volume sampler (Hg: 300) dan dianalisis dengan metode atomic absorption spectrophotometer (AAS). Sampel udara (debu) diambil dalam 3 waktu pengambilan pagi (jam 08.00-09.00), siang (jam 12.00-13.00) dan sore (jam 16.00-17.00). Kadar timbal darah setelah dibuat pengabuan dianalisis dengan metode AAS. Kadar $\mathrm{Hb}$ dengan metode sianmethemoglobin. Analisis data dengan menggunakan analisis deskriptif untuk distribusi dan karakteristik sampel, koefisien Phi dan regresi sederhana untuk hubungan serta uji t untuk perbedaan.

\section{Hasil}

Subyek terdiri dari 75 orang anak, 40 subyek kelompok Pasar 45 didapatkan jenis kelamin 
terbanyak perempuan 28 (70\%) dan dari 35 subyek kontrol 20 (55,5\%) juga perempuan. Pada kelompok Pasar 45 terdapat 32 (80\%) anak bersekolah, dan 30 $(75 \%)$ pekerjaan orangtua adalah pedagang kaki lima (Tabel 1).

Rerata umur kelompok Pasar 45 adalah 9,37 tahun dengan simpang baku (SB) 2,3 tahun. Hasil ini lebih rendah dibandingkan kontrol 10,34 tahun dengan SB 1,41 tahun dan secara statistik bermakna $(\mathrm{p}=0,015)$. Kadar Hb didapatkan lebih rendah pada kelompok Pasar 45 (11,85 g/dL) dengan SB 0,778 g/dL. Hasil ini lebih rendah dibandingkan kontrol $(12,22 \mathrm{~g} / \mathrm{dL})$ dengan SB 0,988 g/dL secara statistik perbedaan ini bermakna ( $\mathrm{p}=0,039)$. Rerata hitung retikulosit lebih tinggi pada kelompok Pasar 45 (0,86\%) dengan SB $0,37 \%$ dibandingkan dengan kontrol yaitu $0,74 \%$

Tabel 1. Karakteristik Subyek

\begin{tabular}{lcc}
\hline Variabel & $\begin{array}{c}\text { Pasar 45 } \\
\mathbf{n}(\%)\end{array}$ & $\begin{array}{c}\text { Kontrol } \\
\mathbf{n}(\%)\end{array}$ \\
\hline $\begin{array}{l}\text { - Jenis kelamin } \\
\text { Laki-laki }\end{array}$ & & \\
$\quad$ Perempuan & $12(30)$ & $15(45,5)$ \\
- Kegiatan sekolah & $28(70)$ & $20(55,5)$ \\
$\quad$ Ada & $32(80)$ & $35(100)$ \\
$\quad$ Tidak & $8(20)$ & 0 \\
- Pekerjaan orang tua & & \\
$\quad$ Pedagang kaki lima (PKL) & $30(75)$ & 0 \\
$\quad$ Buruh harian & $8(20)$ & 0 \\
$\quad$ Sopir & $1(2,5)$ & $10(28,6)$ \\
Pegawai negeri & $1(2,5)$ & $10(28,6)$ \\
Pegawai swasta & 0 & $10(28,6)$ \\
$\quad$ Tukang & 0 & $5(14,2)$ \\
\hline
\end{tabular}

tetapi perbedaan ini secara statistik tidak bermakna $\mathrm{p}=0,072$ (Tabel 2)

Pengukuran kadar timbal di udara telah dilakukan pada 2 lokasi dalam waktu berbeda yaitu lokasi Patung Batalyon Worang pasar 45 dan jalan Pomorow Tingkulu sebagai kontrol pada tanggal 15 dan 16 Juni 2005. Kadar timbal di udara rata-rata lokasi Pasar 45 adalah $0,799 \mathrm{ig} / \mathrm{m} 3$ dan kontrol $0,237 \mu \mathrm{g} / \mathrm{m} 3$ tertera pada Tabel 3.

Pada lokasi Pasar 45 kadar timbal darah antara $10-19 \mu \mathrm{g} / \mathrm{dL}$ terdapat pada satu anak $(2,5 \%)$ dan $>0$ $10 \mu \mathrm{g} / \mathrm{dL}$ sebanyak 39 anak $(97,5 \%)$ sedangkan pada kontrol keseluruhan $(100 \%)$ adalah $<0,2 \mu \mathrm{g} / \mathrm{dL}$ atau tidak terdeteksi (Tabel 4).

Dari hasil analisis statistik koefisien korelasi Phi tidak terdapat hubungan antara kadar timbal udara dengan kadar timbal darah pada anak di Pasar 45 dan kontrol $(\mathrm{p}=0,346)$ seperti tertera pada Tabel 4. Rerata kadar timbal darah kelompok pasar 45 adalah 0,98 $\mu \mathrm{g} / \mathrm{dL}$. Hasil analisis regresi sederhana didapatkan hubungan yang bermakna antara kadar $\mathrm{Hb}$ dengan kadar timbal darah anak di Pasar $45(\mathrm{p}=0,016)$ sesuai

Tabel 3. Kadar timbal udara

\begin{tabular}{lcc}
\hline Jam & Pasar 45 & Kontrol \\
\hline $09.00-10.00$ & 0,615 & 0,150 \\
$12.00-13.00$ & 1,059 & 0,372 \\
$16.00-17.00$ & 0,722 & 0,189 \\
\hline Total & 2,396 & 0,711 \\
Rerata & 0,799 & 0,237 \\
\hline
\end{tabular}

${ }^{*} \mathrm{mg} / \mathrm{m}^{3}$

Tabel 2. Sebaran umur kadar hemoglobin dan hitung retikulosit

\begin{tabular}{|c|c|c|c|}
\hline Variabel & Rerata \pm SB & Uji statistik & kemaknaan \\
\hline \multicolumn{4}{|l|}{ Umur } \\
\hline Pasar 45 & $9,37 \pm 1,41$ & \multirow{2}{*}{2,205} & \multirow{2}{*}{$\mathrm{P}=0,015$} \\
\hline Kontrol & $10,34 \pm 2,34$ & & \\
\hline \multicolumn{4}{|c|}{ Kadar hemoglobin (g/dl) } \\
\hline Pasar 45 & $11,85 \pm 0,988$ & \multirow{2}{*}{1,783} & \multirow{2}{*}{$\mathrm{P}=0,039$} \\
\hline Kontrol & $12,22 \pm 0,778$ & & \\
\hline \multicolumn{4}{|c|}{ Hitung retikulosit (g/dl) } \\
\hline Pasar 45 & $0,86 \pm 0,37$ & \multirow{2}{*}{$-1,476$} & \multirow{2}{*}{$\mathrm{P}=0,072$} \\
\hline Kontrol & $0,74 \pm 0,36$ & & \\
\hline
\end{tabular}


Sari Pediatri, Vol. 8, No. 3, Desember 2006

Tabel 4. Hubungan antara kadar timbal di udara pada kedua lokasi dengan kadar timbal darah

\begin{tabular}{|c|c|c|}
\hline \multirow[b]{2}{*}{$\begin{array}{c}\text { Kadar Timbal Darah } \\
(\mathrm{mg} / \mathrm{dl})\end{array}$} & \multicolumn{2}{|c|}{ Kadar timbal udara (\%) } \\
\hline & Pasar 45 & Kontrol \\
\hline $10-19$ & $1(2,5)$ & 0 \\
\hline$>0-10$ & $39(97,5)$ & $35(100)$ \\
\hline Tot a 1 & $40(100)$ & $35(100)$ \\
\hline
\end{tabular}

Koefisien korelasi Phi $(\mathrm{r} \theta)=0,109, \mathrm{p}=0,346$

Tabel 5. Tidak didapatkan hubungan bermakna antara hitung retikulosit dengan kadar timbal darah anak di Pasar $45(\mathrm{p}=0,812)$ seperti tertera pada Tabel 6.

Tabel 5. Hubungan antara kadar hemoglobin dengan kadar timbal darah anak di pasar 45

\begin{tabular}{lccc}
\hline Model & $\begin{array}{c}\text { Koefisien } \\
\text { regresi }\end{array}$ & $\begin{array}{c}\text { Uji } \\
\text { statistik }\end{array}$ & kemaknaan \\
\hline Konstanta & 11,992 & 75,544 & $\mathrm{P}=0,000$ \\
Kadar timbal darah & $-0,150$ & $-2,518$ & $\mathrm{P}=0,016$ \\
\hline
\end{tabular}

Tabel 6. Hubungan antara hitung retikulosit dengan kadar timbal darah pada anak di Pasar 45

\begin{tabular}{lccc}
\hline Model & $\begin{array}{c}\text { Koefisien } \\
\text { regresi }\end{array}$ & $\begin{array}{c}\text { Uji } \\
\text { statistik }\end{array}$ & kemaknaan \\
\hline Konstanta & 0,856 & 13,100 & $\mathrm{P}=0,000$ \\
Hitung retikulosit & 0,006 & 0,240 & $\mathrm{P}=0,812$ \\
\hline
\end{tabular}

\section{Diskusi}

\section{Karakteristik Anak}

Penelitian ini dilakukan pada 2 kelompok yang berbeda. Pada kelompok Pasar 45 anak tinggal di lokasi Pasar 45 dalam radius $200-500 \mathrm{~m}$ dari tempat pengambilan sampel udara, sedangkan kontrol tinggal di daerah pinggiran kota. Dari 40 sampel Pasar 45 didapatkan 12 (30\%) laki-laki dan 28 (70\%) perempuan. Sedangkan pada 35 sampel kontrol didapatkan 15 (44,5\%) laki-laki dan 20 (55,5\%) perempuan. Kadar timbal darah pada anak dipengaruhi oleh sumber pencemaran yang potensial, lokasi pemukiman/area bermain, aktivitas serta pekerjaan orangtua. ${ }^{17}$ Pada kelompok Pasar 45 terdapat 32(80\%) anak bersekolah sehingga akan menghabiskan waktu sekitar 6 jam di sekolah. Berdasarkan pekerjaan orangtua didapatkan 30 (75\%) adalah PKL sehingga sering melibatkan anak menjaga jualan di dalam Pasar 45.

\section{Gambaran kadar timbal di udara}

Pengukuran kadar timbal di udara pada penelitian ini dilakukan dalam periode pendek (spot sampling) $)^{12}$ dengan tiga waktu yang berbeda. Kadar rata-rata timbal di udara ambien mencapai $0,799 \mu \mathrm{g} / \mathrm{m}^{3}$. Hasil ini lebih rendah dari yang dilaporkan Warouw ${ }^{11}$ pada Mei 2003 yaitu $1,789 \mu \mathrm{g} / \mathrm{m}^{3}$. Kadar timbal udara pada penelitian ini masih di bawah baku mutu udara ambien yang diberlakukan oleh WHO yaitu $1 \mu \mathrm{g} / \mathrm{m}^{3}$ atau oleh EPA yaitu $1,5 \mu \mathrm{g} / \mathrm{m}^{3}$ ataupun menurut PP No.41 tahun 1999 yaitu $2 \mu \mathrm{g} / \mathrm{m}^{3}{ }^{2,13-15}$

Menurut Darmono ${ }^{15}$ dan Harsanto, ${ }^{16}$ berat ringannya suatu pencemaran udara di suatu daerah sangat bergantung pada iklim lokal, topografi, kepadatan penduduk, banyaknya industri yang berlokasi di daerah tersebut, penggunaan bahan bakar dalam industri, suhu udara panas di lokasi dan kesibukan transportasi. Selain itu curah hujan akan sangat membantu proses pembersihan udara, angin yang kencang dapat menyapu polutan ke daerah lain, serta semakin besar angin semakin kecil konsentrasi zat polutan karena akan mengalami pengenceran.

Lokasi pusat Kota pasar 45 berada di pinggir pantai dekat pelabuhan laut Manado dengan kecepatan angin cukup tinggi dan pada tahun 2004 sampai pertengahan tahun 2005 curah hujan di Kota Manado cukup tinggi (sumber Meteorologi dan Geofisika). Selain itu sejak pertengahan tahun 2003 telah dibuka pusat perbelanjaan baru di sepanjang Manado Boulevard, seperti kawasan Mega Mas, Marina ITC, dll. Juga telah dibaginya jalur kendaraan umum dengan trayek tertentu saja yang melewati Pasar 45 (Sumber Dinas Perhubungan). Hal-hal tersebut telah mempengaruhi dan mengurangi polusi udara akibat gas buang kendaraan bermotor di tempat tersebut. Sebagai pembanding didapatkan kadar timbal udara lebih rendah di daerah kontrol Jl. Pomorow Tingkulu yaitu rata-rata $0,237 \mu \mathrm{g} / \mathrm{m}^{3}$. Lokasi jalan ini adalah pinggiran kota dengan 
Sari Pediatri, Vol. 8, No. 3, Desember 2006

kesibukan transportasi yang kurang, tidak terdapat terminal sehingga relatif tidak terjadi kemacetan serta ditumbuhi banyak pepohonan.

\section{Gambaran kadar timbal darah}

Menurut klasifikasi CDC 1991 semua anak dengan kadar timbal darah $>10 \mu \mathrm{g} / \mathrm{dL}$ disebut menderita "keracunan timbal $(\mathrm{Pb})$ ", dan kadar 10-19 $\mu \mathrm{g} / \mathrm{dL}$ sebagai "keracunan timbal ringan". ${ }^{8,17,18}$ Berdasarkan definisi tersebut terdapat 1 sampel kelompok Pasar $45(2,5 \%)$ mempunyai kadar timbal darah $14,2 \mu \mathrm{g} /$ $\mathrm{dL}$ sebagai menderita keracunan timbal ringan. Rerata kadar timbal darah kelompok pasar 45 adalah $0,98 \mathrm{ig} / \mathrm{dL}$. Kadar timbal darah pada penelitian ini lebih rendah dari yang dilaporkan oleh PPK UI dari 400 anak kelas II dan III SD di Jakarta ditemukan $34,4 \%$ anak mempunyai kadar timbal darah $>10$ $\mu \mathrm{g} / \mathrm{dL}$ dengan rerata $8,6 \mu \mathrm{g} / \mathrm{dL}$. Hasil ini hampir sama dengan yang dilaporkan Fathoni dkk, ${ }^{10}$ pada 47 sampel usia 6-24 bulan terdapat 45 (95,74\%) kadar $\mathrm{Pb}$ darah $0-<10 \mu \mathrm{g} / \mathrm{dl}$ dan 2 (4,26\%) kadar $\mathrm{Pb}$ darah 10-14 $\mu \mathrm{g} / \mathrm{dL}$. Sebagai pembanding kadar timbal darah pada PKL yang di laporkan Warouw, ${ }^{11}$ dari 60 sampel berusia 20 tahun terdapat 56 sampel $(93,3 \%)$ telah mempunyai kadar timbal darah $>20$ $\mu \mathrm{g} / \mathrm{dL}$.

\section{Hubungan antara kadar timbal di udara dengan kadar timbal darah anak}

Pada penelitian ini tidak ditemukan hubungan antara kadar timbal di udara pada ke 2 lokasi dengan kadar timbal darah anak. Hal ini disebabkan kadar timbal di udara di tempat tersebut dapat berubah-ubah dipengaruhi oleh banyak faktor dan sifat mobilitas anak yang tinggi. Menurut Goldsmith dan Hexter (dikutip dari Piomelli) ${ }^{5}$ terdapat hubungan yang jelas yaitu hubungan logaritmik antara kadar timbal udara dengan kadar timbal darah. Patterson (dikutip dari Piomelli) ${ }^{5}$ mendapatkan bahwa kadar timbal $(\mathrm{Pb})$ darah adalah rendah pada kadar timbal udara yang rendah dan sesegera mungkin meningkat diikuti pula oleh peningkatan kadar $\mathrm{Pb}$ darah. Colombo (dikutip dari WHO IPCS $)^{14}$ melaporkan bahwa pada kadar timbal di udara 1,1-2,0 $\mu \mathrm{g} / \mathrm{dL}$ dan kadar timbal darah $<30$ $\mu \mathrm{g} / \mathrm{dL}$, hubungan digambarkan linier.

\section{Hubungan antara kadar hemoglobin dengan kadar timbal darah anak di pasar 45}

Pada penelitian ini didapatkan hubungan yang bermakna antara kadar $\mathrm{Hb}$ dengan kadar $\mathrm{Pb}$ darah anak di pasar 45. Ini disebabkan terdapat kekhususan yaitu 1 anak dengan kadar timbal darah $14,2 \mu \mathrm{g} / \mathrm{dL}$ mempunyai kadar $\mathrm{Hb}$ 9,6 g/dL, sehingga pada analisa regresi didapatkan hubungan yang bermakna. Kadar $\mathrm{Hb}$ juga dipengaruhi oleh beberapa faktor lain yang tidak diteliti pada penelitian ini misalnya anemia defisiensi besi, investasi cacing, dll. Sesuai kepustakaan, bahwa untuk mengetahui penyebab kadar $\mathrm{Hb}$ yang rendah perlu dievaluasi lebih lanjut morfologi darah, MCV serta kadar ferritin serum untuk menyingkirkan anemia defisiensi besi. ${ }^{5,17}$

Beberapa penelitian melaporkan bahwa anemia dapat dilihat pada anak hanya pada kasus-kasus berat atau ditemukan bersamaan dengan defisiensi besi., ${ }^{5,14,17}$ Di lain pihak keracunan timbal dan defisiensi besi cenderung terjadi pada populasi dengan sosioekonomi rendah yang berhubungan dengan defisiensi gizi. Defisiensi besi dapat meningkatkan retensi dan toksisitas timbal. ${ }^{5}$ Anemia yang didefinisikan sebagai suatu hematokrit di bawah 35\% tidak ditemukan pada kadar timbal darah $<20 \mu \mathrm{g} / \mathrm{dL} .{ }^{14}$ Ambang kadar timbal darah untuk menurunkan kadar $\mathrm{Hb}$ pada anak diperkirakan $40 \mu \mathrm{g} / \mathrm{dL} .{ }^{17}$

\section{Hubungan antara hitung retikulosit dengan kadar timbal darah anak di pasar 45}

Sesuai kepustakaan disebutkan bahwa ada 2 mekanisme utama terjadinya anemia yaitu menurunnya sintesis $\mathrm{Hb}$ dan terjadinya hemolisis. Penurunan sintesis hemoglobin disebabkan oleh karena gangguan pada beberapa langkah enzimatik heme pathway. Pada paparan yang lama dengan kadar timbal yang tinggi, masa hidup erittrosit memendek dan dihubungkan dengan inhibisi pada pyrimidine 5-nucleotidase yang selanjutnya menyebabkan anemia hemolitik yang ditandai retikulosis. ${ }^{4,5,8,14,19}$ Pada penelitian ini tidak didapatkan hubungan yang bermakna antara hitung retikulosit dengan kadar timbal darah anak di Pasar 45. Kadar timbal darah anak tertinggi $14,2 \mu \mathrm{g} / \mathrm{dl}$ dan sesuai CDC 1991 berada pada keracunan ringan, 
sehingga tidak tampak tanda anemia dan hemolisis yang berat. Menurut Hurwitz dan Lee, ${ }^{17}$ anemia hemolitik tampak jelas pada kadar timbal darah $>70$ $\mu \mathrm{g} / \mathrm{dL}$.

\section{Keterbatasan}

Faktor arah dan kecepatan angin perlu diukur atau dikendalikan dan diperlukan perhitungan jumlah kendaraaan rata-rata yang melewati Pasar 45.

\section{Kesimpulan}

Kadar timbal udara di Pusat Kota Pasar 45 saat penelitian belum melebihi ambang baku mutu udara. Tidak terdapat hubungan antara kadar timbal udara dengan kadar timbal darah di Pasar 45 dan kontrol. Terdapat hubungan yang bermakna antara kadar $\mathrm{Hb}$ dengan kadar timbal darah anak di Pasar 45. Tidak terdapat hubungan antara hitung retikulosit dengan kadar timbal darah anak di Pasar 45. Walupun masih dalam derajat ringan telah terjadi peningkatan kadar timbal darah anak di Pusat Kota Pasar 45 Manado.

\section{Daftar Pustaka}

1. Sinar Harapan. Pencemaran udara semakin parah, industri otomotif terapkan standar emisi Euro 2. Didapat dari: http://www.sinarharapan.co.id/feature/ otomoti/ 2003/ 0828/oto.i.html, diakses 0ktober 2004.

2. Pirngadie BH. Strategi penanggulangan pencemaran udara dari sektor transportasi. Simposium ke-4 FS TPT Udayana Bali, November, 2001.

3. Kompas. Siswa SD di Jakarta tercemar timbal. Didapat dari: http://kompas.com/kompas-cetak/0406/08/metro/ 1071306.htm, diakses Juni 2004.

4. Goyer RA. Lead. Dalam: Amdur. MO, Doull J, Klaasen CD, Penyunting. Casarett and Doull's Toxicology.Edisi ke-4. New York : Mc Grawhill Inc, 1991;623-46.

5. Piomelli S. Lead Poisoning. Dalam: Nathan DG, Oski FA, Penyunting. Hematology of infancy and childhood. Edisi ke-4. Philadelphia: WB Sounders Co, 1993; 47390.

6. Katzung BG. Toksikologi Logam berat. Dalam:
Kotualubun BH dkk. Alih bahasa. Farmakologi dasar dan klinik (Basic and Clinical Pharmacology). Edisi 3. Jakarta : EGC, 1995. h. 870-3.

7. Lidsky TI, Schneider JS. Lead neurotoxicity in children: basic mechanisms and clinical correlates. Brain 2003; 126:5-19.

8. Piomelli S. Lead Poisoning. Dalam: Behrman RE, Vaughan VC, Nelson WE, penyunting. Nelson Texbook of Pediatric. Edisi ke -16. Philadelphia: WB Saunders Co, 2000; 2156-60.

9. Mukono HJ. Pencemaran Logam berat Timbal (Pb) dan mercuri $(\mathrm{Hg})$ dampak terhadap kesehatan dan usaha pencegahannya. Dalam: Ismoedijanto dkk penyunting. Pediatri pencegahan mutakhir II. Surabaya: SMF IKA FK UNAIR, 2004. h. 1-7

10. Fathoni TF, Rusmil K, Tanuwidjaja S. Kadar plumbum (Pb) darah pada anak pekerja pabik tekstil usia 6-24 bulan di daerah industri tekstil. Abstrak Konika XI, Jakarta 4-7 Juli 1999:550.

11. Warouw F. Analisis hubungan kadar $\mathrm{Pb}$ dalam darah dengan lama kerja pedagang kaki lima di pusat kota manado akibat pemaparan gas buangan kendaraan bermotor yang mengandung $\mathrm{Pb}$. Tesis. Manado: Program Pasca Sarjana IKM Unsrat, 2004.

12. Rao MN, Rao HVN, penyunting, Air Pollution. Edisi ke-5. New Delhi :Tata McGraw-Hill Pub.1993. h. 96100.

13. Fardiaz S, penyuting. Polusi air dan udara. Jakarta: Penerbit Kanisius, 1992. h. 134-44.

14. WHO. Inorganic lead. Environmental health criteria 165. IPCS WHO. Geneva. 1995.

15. Darmono, penyunting. Lingkungan hidup dan pencemaran. Edisi I. Jakarta: UI Press;2001. h. 9-27.

16. Harsanto JBB. Pencemaran udara, pengaruh serta cara penanggulangannya. Seminar Nasional Lingkungan Hidup: Strategi kebijakan pengendalian pencemaran udara dalam menuju program langit biru. Yogjakarta, 9 Mei 2001

17. Hurwitz RL, Lee DA. Childhood lead poisoning: Clinical manifestation and diagnosis. CD ROM up to date versi 12,3 2004. Last changed on August 7, 2003.

18. Rudolph AM, Robert K, Kamci. Lead screening. Rudolph's Fundamentals of pediatrics, Edisi ke-3,New York : Chapman \& Hall, 2002. h. 48-51.

19. Lileyman JS, Hann IM, Blanchette VS, penyunting. Lead. Pediatric Hematology, Edisi ke-2 London: Churchill Livingstone, 2000. h. 784-5. 